J. Product. \& Dev., 18(3):405 - 420 (2013)

\title{
INFLUENCE OF COLORED PLASTIC MULCHES ON GERMINATION, GROWTH AND MARKETABLE YIELD OF POTATO
}

\section{S.S.M. Al-Zohiri and M. M. Samy}

Potato and Vegetatively Propagated Vegetables Dep., Hort. Res., Inst., A.R.C., Egypt.

\section{ABSTRACT}

Two field experiments were conducted at Kaha Vegetables Research Farm, Horticulture Research Institute, Agriculture Research Centre during 2011/2012 and 2012/2013 winter seasons to investigate the effect of colored plastic mulches (black-red-blue) on germination, growth and production stages, as well as, chemical constituents of potato $\mathrm{cv}$. Diamant.

The obtained results showed that there were differences among the tested colored plastic mulches in germination, vegetative growth aspects, yield and its components, as well as, chemical constituents. Obtained data indicated also that, the black mulch was significantly increase in germination rate and number of stems per plant, whereas; red mulch exhibited the highest values in all studied growth traits, yield and its components. Although, the lowest values were obtained as a result of using bare soil treatment. However, the differences between the red and black mulches did not reach to the level of significance in stem length, number of main stems per plant, number of leaves per plant and leaf area.

Conclusively, from the above-mentioned investigation, it can be concluded that utilizing red plastic mulch in the winter on the soil can raise the temperature and moisture around the root zone to get the highest and fastest rate of emergence of the potato seed tubers as well as increasing the vegetative growth parameters, higher total yield and marketable yield with lower production costs than bare soil.

Key words: Potatoes, colored mulches, germination \& growth initiation, Vegetative growth, Marketable yield.

\section{INTRODUCTION}

Potato (Solanum tuberosum L.) is one of the most important and strategic vegetable crops in Egypt for both local consumption and export. Consumption of potato in developing countries, including Egypt is still less 
than a quarter of that in Europe, but the evidence suggests it will increase strongly in the future (FAO, 2008), thus, new systems of production that allow higher yields and good quality are needed in order to meet the increasing demands. Growth of a potato plant occurs in several stages: germination, development, plant establishment, tuber initiation, tuber bulking, and tuber maturation. Timing of these growth stages varies depending upon environmental factors, such as elevation and temperature, soil type, availability of moisture. The highest soil temperatures were obtained under plastic mulch, Suwon and Judah (1985), (Park et al., 1987), Fortnum et al., 1995 and Petrov and Al-Amiri, 1976) they reported that soil temperature increased with the use of plastic mulch and the black mulch was effective more than the control and other colors. Moreover, increased moisture retention capacity due to mulching with polyethylene could be attributed to less evaporation from the soil. Because of vapors, the water was further trapped within the mulches, resulting in fog, which again dropped into the upper soil layer. Wang et al., (1998) and Ashrafuzzaman et al., (2011) reported that all type of polyethylene mulch increased the soil moisture content compared to control. Other studies have considered the relationship between plastic mulch and germination of potato seed tubers, Masud et al., (2002). Jalil et al., (2004) and Ferdoushiet al., (2010). In this review, the authors demonstrated that, potato seed tubers planted under black plastic mulch took minimum and or shortest time (13.92 days) to reach $80 \%$ emergence.

Vegetative growth and yield also was affected by using plastic mulches. Coling (1997) revealed that plastic film mulches increased plant height, leaf area index, dry matter accumulation and tuber yield of potato. Singh and Zakwan (2008) Mulching had significant influence on potato growth and yield. Emergence, plant height, and number of stems improved with black polythene mulching. Ahmad et al., (2009) found that mulching with black polyethylene significantly increased the yield/ plant and total yield as compared with the control. In addition, Sadik et al., (2009) reported that mulching potato plants using black polyethylene significantly increased the percentage of dry matter in potato tubers. Ferdoushi et al. (2010) suggested that the highest yield of potato tuber $(25.53 \mathrm{t} / \mathrm{ha})$ was obtained from the plants grown over black polythene mulch and the lowest (13.68 $\mathrm{t} / \mathrm{h}$ ) from the plants given no mulch treatments. Contra results, reported by Al-jubouri (2011) reveal that plant height and leaf area per plant, the length of tuber, diameter, weight and number of tubers per plant and the marketable yield was recorded under red plastic comparative with nonmulching, while the black plastic was recorded highest number of leaves and stems per plant comparative with non-mulching and yellow plastic. Al- 
juboori (2013) on garlic reported that, mulching has shown plants grown under Red Polyethylene superiority in all characteristics of vegetative growth and yield compared with cultivated without mulch.

Therefore, the main objective of the present study was to evaluate effect of colored plastic mulches on germination, growth and yield stages of potato.

\section{MATERIALS AND METHODS}

\section{Site description:}

The experiment was conducted on clay loam soil at the research farm of Kaha Kalyoubia Gov. Egypt, during two successive winter seasons of 2011/2012 and 2012/2013, to investigate the effect of mulching treatments (no-mulching, mulching with black, blue and red sheets of 80 micron thickness) on soil temperature, moisture, germination, growth parameters and marketable yield and its quality, as well as, chemical composition of potato (Solanum tuberosum L.) cv. Diamant. The site is located at an altitude of $21.1 \mathrm{~m}$ above sea level, latitude $30^{\circ} 16^{\prime} \mathrm{N}$ and longitude $31^{\circ} 12^{\prime} \mathrm{E}$. Chemical and physical properties of the experimental field are shown in Table 1.

Table 1. The physical and chemical properties of the experimental soil.

\begin{tabular}{|l|c|c||}
\hline \multirow{2}{*}{ Properties } & \multicolumn{2}{|c|}{ Fall seasons of } \\
\cline { 2 - 3 } 1- Physical & $\mathbf{2 0 1 1 / 2 0 1 2}$ & $\mathbf{2 0 1 2 / 2 0 1 3}$ \\
Clay (\%) & 60.70 & 60.40 \\
Silt (\%) & 21.10 & 22.00 \\
Sand (\%) & 18.20 & 17.60 \\
Texture & Clay loam & Clay loam \\
\hline 2- Chemical (available) & & \\
N (ppm) & 98.90 & 99.60 \\
P (ppm) & 5.90 & 4.66 \\
K (ppm) & 216.2 & 215.6 \\
pH & 7.70 & 7.60 \\
\hline
\end{tabular}

\section{Experimental design:}

The experiment was laid out in a randomized complete block design with three replications. Each experimental plot included five ridges $4 \mathrm{~m}$ length and $75 \mathrm{~cm}$ width with an area about $15.0 \mathrm{~m}^{3}$, where 4 ridges were planted and the fifth one was left without planting as a guard ridge between plots. All data collected were subjected to analysis of variance (ANOVA) to test treatment effects for significance using Statistix 9.0 software package. The means were compared using F-LSD. 
Planting technique:

Uniform size seed tubers of potato. cv. Diamant were planted on $15^{\text {th }}$ and $17^{\text {th }}$ November in $2011 / 2012$ and 2012/2013, respectively on the top of the ridges in the hills, which were prepared for this purpose in the soil at 25 $\mathrm{cm}$ deep and at a distance $25 \mathrm{~cm}$ apart. The surface drip irrigation system was applied and the space between the dripper and other one was $25 \mathrm{~cm}$ and between the hills were $10 \mathrm{~cm}$. In addition, $35 \mathrm{~m}^{3}$ farm yard manure plus 90 $\mathrm{kg} \mathrm{P}_{2} \mathrm{O}_{5} /$ fed. phosphorus fertilizer were mixed together and added during soil preparation. Potato plants were supplied with ammonium sulphate (20.6 $\% \mathrm{~N}$ ) as a source of nitrogen fertilizer at a rate of $150 \mathrm{~kg} \mathrm{~N} / \mathrm{fed}$. The total amount of $\mathrm{N}$-fertilizer was divided into two equal portions added at 40 and 60 days after planting. While potassium fertilizer was added as potassium sulphate $\left(48-52 \% \mathrm{~K}_{2} \mathrm{O}\right)$ at a rate of $96 \mathrm{~kg} \mathrm{~K}_{2} \mathrm{O} /$ feddan at two times, i.e., half of the total potassium amount was applied before planting (during soil preparation), whereas the rest of potassium was added at complete plant emergence (45 days from planting). Soil temperature were taken at $10 \mathrm{~cm}$ depth using a digital soil temperature tester between 2:00 and 4:00 pm twice weekly throughout the duration of the experiment as shown in Figure (1), during the growing season the follow date were recorded.

Soil moisture measurement: Soil moisture content under plastic mulches and bare soil was measured twice every one month (6 times during 120 days); three soil samples were taken from each experimental plot at $20 \mathrm{~cm}$ depth they are collected in airtight aluminum containers. The soil samples are weighed and they are dried in an oven at $105 \mathrm{oC}$ for about 24 hours until all the moisture is driven off. After removing from oven, they are cooled slowly to room temperature and weighed again. The difference in weight is amount of moisture in the soil. The moisture content in the soil is calculated by the following formula:-

Weight basis $=$ Wet weight - Dry weight / Dry weight $\mathrm{x} 100$

Emergence rate: Emergence rate is the average number of potato seed tubers that germinate over the five and ten day periods.

$$
\text { Germination }(\%)=\frac{\text { Number of seeds germinated }}{\text { Number of seeds planted in the plot }} \times 100
$$

Days required to $100 \%$ emergence: This was achieved by recording the number of days taken for the emergence of 64 seed tubers planted in each plot.

1. Growth initiation: At 40 days after planting five plants per each experimental were choosing randomly and measured and counted to record the following date:

1-1- Plant height $(\mathrm{cm})$ from soil surface to the highest top.

1-2- Number of stems / plant. 


\section{2- Vegetative growth characteristics:}

Three plants from each experimental plot were taken randomly at 75

days after planting and the following data were recorded:

2-1- Stem length.

2-2- Number of main stems.

2-3- Number of leaves per plant.

2-4- Leaf area per plant was determined by cutting out 20 leaf discs from each plant using a cork borer and dried them in an oven at $75 \mathrm{C}^{\circ}$ (until constant weight). The rest of the leaves were similarly dried. Based on the known dry weight of a known surface area of leaves, i.e., leaf discs, and the total weight of leaves, leaves surface area was determined. The different plant organs were oven dried at $75 \mathrm{C}^{\circ}$ and the dry weight of these organs were recorded.

2-5- Leaves dry weight.

2-6- No. of tubers per plant.

2-7- Average tuber weight (g).

2-8- Tubers weight per plant (g).

\section{3- Yield and its components:}

At harvesting time (120 days after planting) all tubers of each experimental plot were harvested after removal of plant foliage above ground surface, then tubers were cleaned from the soil and the following data were recorded:

3-1. Marketable tubers yield (ton/fed.) which included all tubers measuring $>2$ " in diameter.

\section{4- Chemical constituents of tubers:}

In the digested dry matter of leaves, nitrogen was determined according to the methods described by Pregl (1945) using micro-kjeldahl apparatus. Meanwhile, phosphorus was estimated calorimetrically according to the method described by Murphy and Riley (1962) modified by John (1970). Furthermore, potassium was determined flam-photometrically as described by Brown and Lilleland (1946).

Chlorophyll content: It was estimated according to the method described by Yoshida et al., (1976).

\section{5- Cost benefits analysis.}

The cost of production was analyzed with a view of find out the most profitable treatments. All the non-material and material input costs and interests on running capital were considered for computing the cost of production. Cost and return analysis was done in details according to the procedure of Perkins (1994). Benefit cost ratio was calculated by the following formula: 
Benefit cost ratio $=$ Gross return $(\mathrm{LE} / \mathrm{fed}$.)/Total cost of production $(\mathrm{LE} / \mathrm{fed}$.).

\section{RESULTS AND DISCUSSIONS}

\section{1- Soil temperature.}

Soil temperature at the $15 \mathrm{~cm}$ depth was different due to the presence of colored mulches (Figure 1). Soil temperature varied considerably with type of mulching of soil. Temperature under mulches was higher than that of the control plots for all the months. The maximum difference in temperatures between mulched and control plots were 6.65 to $8.92{ }^{\circ} \mathrm{C}$ in the $2011 / 2012$ and 4.37 to 7.53 in 2012/2013. The black plastic mulch produced higher soil temperatures followed by the red mulch. In general, soil temperature was higher under plastic mulch. These results are in agreement with those obtained by Suwon and Judah (1985) reported that soil temperature increased with the use of plastic mulch. The polythene mulches allowed part of the radiation to pass through it but acted as barriers against outgoing thermal radiation (Park et al., 1987). Variability of soil temperature in the upper few $\mathrm{cm}$ of the soil was likely due to the color of the mulch (Fortnum et al., 1995; Petrov and Al-Amiri, 1976).

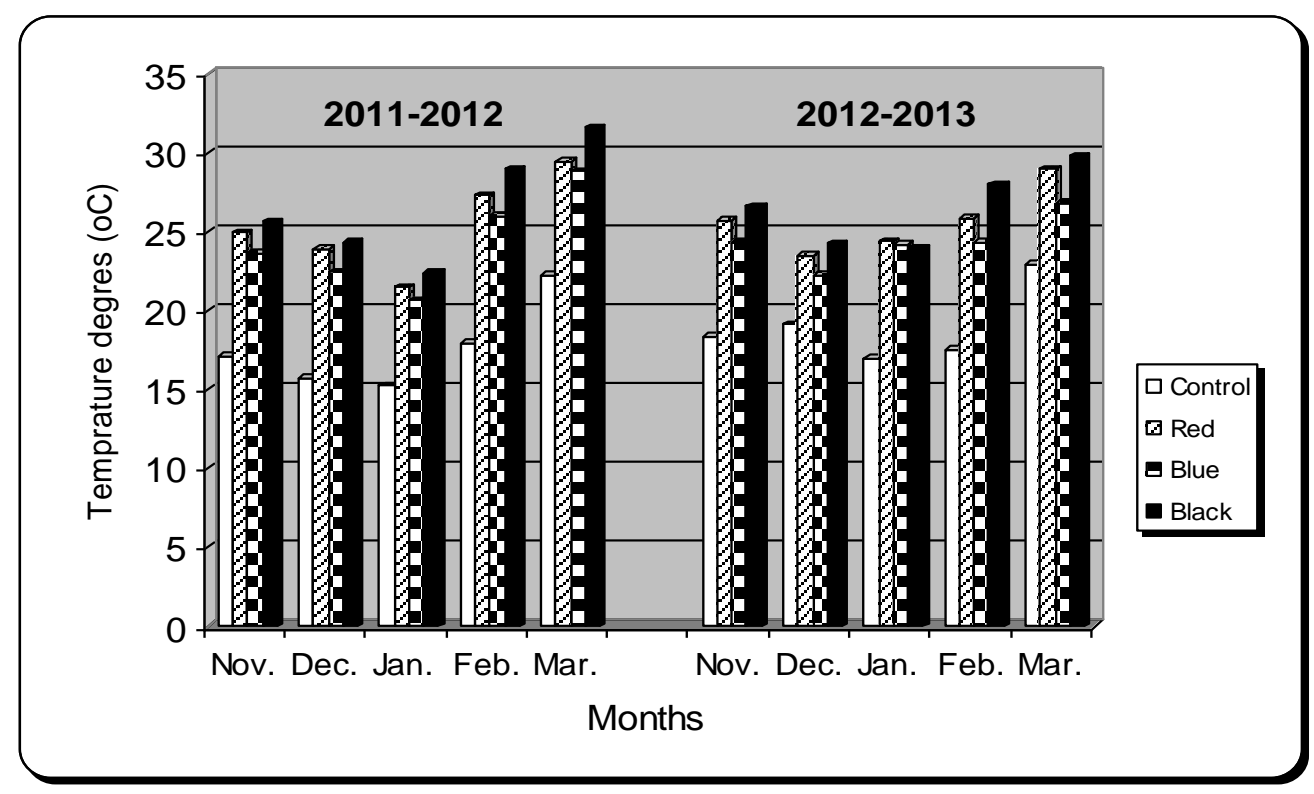

Figure 1. Measured soil temperatures for all treatments during the growing season in years 2011/2012 and 2012/2013. 


\section{2- Soil moisture:}

The soil moisture content in the experimental plots under different mulches was measured within $15 \mathrm{~cm}$ depth. Results revealed that all the mulches retained higher amount of soil moisture compared to the control (Figure 2). However, among the mulches, there was no significant difference in soil moisture content. The red polyethylene mulch apparently showed highest moisture $(23.45 \%)$, followed by black $(22.75 \%)$ and blue $(20.88 \%)$ polyethylene mulch. The lowest moisture $(16.52 \%)$ was recorded in the bare soil treatment. Increased moisture retention capacity due to mulching with polyethylene could be attributed to less evaporation from the soil. Because of vapors, the water was further trapped within the mulches, resulting in fog, which again dropped into the upper soil layer. Wang et al. (1998) and Ashrafuzzaman et al. (2011) they reported that all type of polyethylene mulch increased the soil moisture content compared to control.

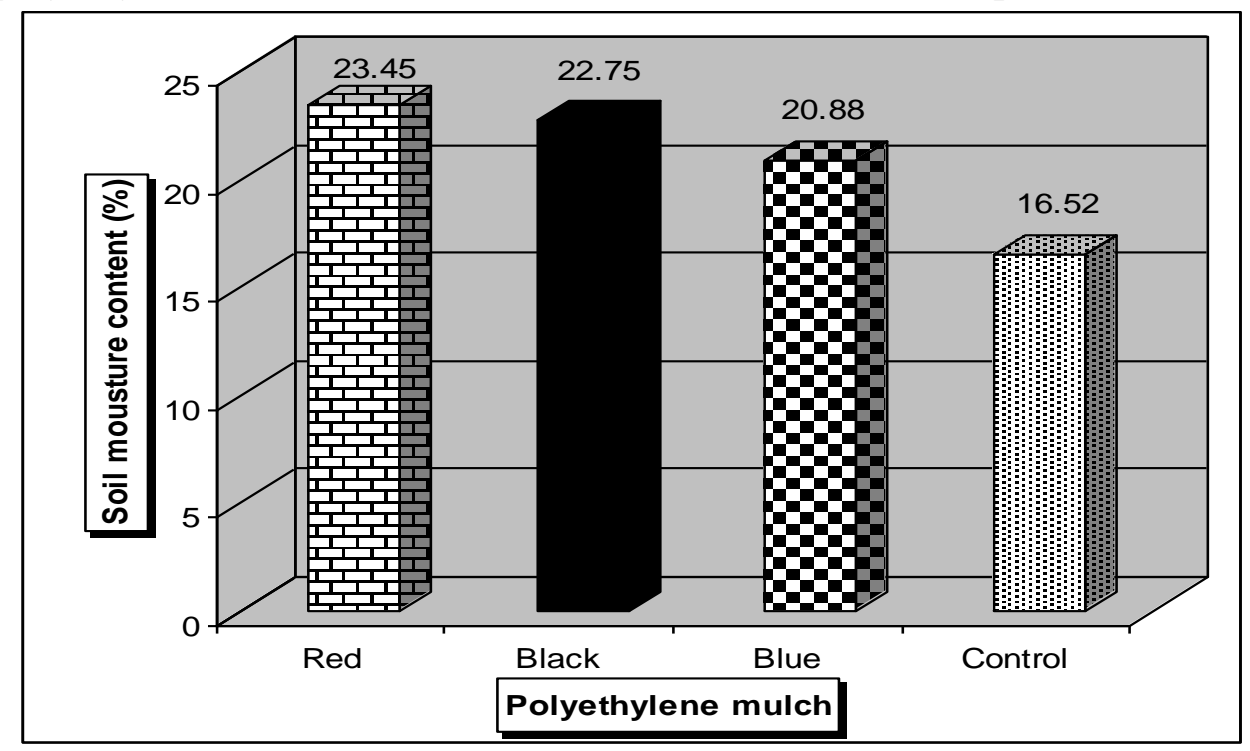

Figure 2. Soil moisture percentage at $0-20 \mathrm{~cm}$ depth under different polyethylene mulches.

\section{3-Germination and growth initiation.}

Data presented in Table 2 reveal that mulching has very positive effect on emergence and growth initiation. Emergence was maximum under black plastic mulch after 24.74 days of planting whereas, it was minimum $91.67 \%$ in the first season and $89.50 \%$ in the second one with 31.07 and 31.60 days of planting. The highest emergence was 98.6 and $97.93 \%$ in both seasons respectively, under black mulch, emergence percentage, time required for $100 \%$ emergence of the tubers seed. Stem length and number 
Table 2. Effect of colored plastic mulches on germination and growth initiation at 40 days after planting.

\begin{tabular}{|l|c|c|c|c|}
\hline & $\begin{array}{c}\text { Emergence } \\
(\boldsymbol{\%})\end{array}$ & $\begin{array}{c}\text { Days to } \\
\mathbf{1 0 0 \%} \\
\text { Emergence }\end{array}$ & $\begin{array}{c}\text { Plant height } \\
\text { Plastic colors }\end{array}$ & $\begin{array}{c}\text { No. of main } \\
\text { stems per } \\
\text { plant }\end{array}$ \\
\cline { 2 - 5 } & \multicolumn{4}{|c|}{$\mathbf{2 0 1 1 / 2 0 1 2}$} \\
\hline Control & 91.67 & $31.07 \mathrm{a}$ & 11.47 & 1.83 \\
Bed & 95.27 & $26.35 \mathrm{~b}$ & 17.93 & 3.27 \\
Blue & 93.67 & $26.83 \mathrm{~b}$ & 15.80 & 2.31 \\
\hline L.S.D. at $\mathbf{0 . 0 5}$ & 98.60 & $24.74 \mathrm{~b}$ & 23.77 & 4.30 \\
\hline & $\mathbf{1 . 7 4}$ & $\mathbf{2 . 4 2}$ & $\mathbf{1 . 3 1}$ & $\mathbf{0 . 7 5}$ \\
\hline Control & \multicolumn{4}{|c|}{$\mathbf{2 0 1 2 / 2 0 1 3}$} \\
Red & 89.50 & 31.60 & 9.87 & 1.86 \\
Blue & 96.93 & 26.02 & 18.33 & 3.28 \\
Black & 94.67 & 26.85 & 5.80 & 2.36 \\
\hline L.S.D. at $\mathbf{0 . 0 5}$ & 97.93 & 24.96 & 24.5 & 4.13 \\
\hline
\end{tabular}

of stems per plant at 40 days after planting (DAP) were significantly influenced by different color of plastic mulch used. The black plastic mulch covered gave the uppermost values compared with other treatments. Maximum average emergence (98.6 and 97.93\%), stem length (23.77 and $24.50 \mathrm{~cm}$ ) and number of stems per plant (4.30 and 4.13) were recorded with black plastic mulch during first and second season, respectively. On the other hand, the bare soil needed maximum time (31.34 days) to emergence compared with black plastic covered that recorded (24.74 days) only. The highest emergence percentage and the shortest time required for $100 \%$ emergence were obtained with black plastic mulching, that may be attributed to rising the soil temperature (Fig.1) and conservation of more soil moisture (Fig.2) in the black polyethylene covered soil that enhancing and encouraged earlier tuber emergence. These results were in agreement with those reported by; Masud et al. (2002), Jalil et al., (2004) Singh and Zakwan (2008) and Ferdoushi et al. (2010) all working on potato they reported that mulching has very positive effect on emergence of potato seed tubers and black polythene mulch took the shortest time (14.3 day) and the non-mulch needed maximum time (15.7day) to emergence.

\section{4-Vegetative growth characteristics:}

Data recorded in Table 3 clearly indicate that, vegetative growth parameters of potato plants expressed as stem length, number of main stems and number of leaves per plant, as well as, leaf area were significantly increased when potato crop was planted using colored plastic mulches 
Table 3. Effect of colored plastic mulches on vegetative growth characteristics 75 days after planting during 2011/2012 and 2012/2013 seasons.

\begin{tabular}{||l|c|c|c|c|c||}
\hline \multirow{2}{*}{ Plastic colors } & $\begin{array}{c}\text { Stem } \\
\text { length }\end{array}$ & $\begin{array}{c}\text { Number } \\
\text { of main } \\
\text { stems }\end{array}$ & $\begin{array}{c}\text { Number } \\
\text { of leaves } \\
\text { / plant }\end{array}$ & $\begin{array}{c}\text { Leaf area } \\
\text { per plant } \\
\text { (cm }\end{array}$ & $\begin{array}{c}\text { leaves dry } \\
\text { weight } \\
\text { (g/plant) }\end{array}$ \\
\cline { 2 - 6 } & \multicolumn{5}{|c|}{$\mathbf{2 0 1 1 - 2 0 1 2}$} \\
\hline Control & 35.67 & 2.67 & 43.00 & 1899.95 & 69.70 \\
\hline Red & 46.00 & 4.00 & 71.67 & 2897.70 & 133.07 \\
\hline Blue & 43.33 & 3.00 & 37.67 & 2113.44 & 84.35 \\
\hline Black & 43.67 & 3.00 & 38.33 & 2175.79 & 98.94 \\
\hline L.S.D. at 5\% & $\mathbf{5 . 7 6}$ & $\mathbf{1 . 7 3}$ & $\mathbf{3 2 . 3 6}$ & $\mathbf{7 6 4 . 3 1}$ & $\mathbf{2 9 . 3 6}$ \\
\hline & & \multicolumn{5}{|c|}{$\mathbf{2 0 1 2 - 2 0 1 3}$} \\
\hline Control & 35.33 & 3.00 & 43.00 & 1862.95 & 70.38 \\
\hline Red & 45.33 & 4.00 & 70.33 & 2860.78 & 128.35 \\
\hline Blue & 44.33 & 3.00 & 36.33 & 1994.30 & 85.53 \\
\hline Black & 43.00 & 2.67 & 37.33 & 2101.12 & 105.74 \\
\hline L.S.D. at5\% & $\mathbf{3 . 2 1}$ & $\mathbf{0 . 5 8}$ & $\mathbf{1 1 . 5 5}$ & $\mathbf{6 0 1 . 7 1}$ & $\mathbf{1 4 . 9 8}$ \\
\hline
\end{tabular}

compared with the bare soil treatment during both seasons of this study. In this respect, using red plastic mulch reflected the highest values in all measured growth traits followed by black plastic mulch compared with black plastic color and control. However, there were no significant differences among the black and blue mulches treatments in stem length and number of main stems per plant during both seasons of this study. Moreover, the bare soil treatment produced the lowest results in this respect. Obtained results from bare soil may be attributed to lower soil temperature, which may effect on enzymatic reaction which affection on buds initiation and growth consequently the increase in the number of days to $100 \%$ emergence (Table 3). This result were conformity with recorded by, Coling (1997) and Al-jubouri (2011) on potato reported that red plastic mulch have the greatest impact on plant growth. The highest value by characteristics of plant height and leaf area per plant. Al-juboori (2013) on garlic reported also that red polyethylene mulch superiority in all characteristics of vegetative growth compared with cultivated without mulch.

\section{Yield and yield attributes:}

Data presented in Table 4 show that, there were significant differences among colored plastic mulches and the control treatment. In this 
Table 4. Yield and yield attributes of Potato tubers as affected by plastic colored mulches.

\begin{tabular}{|c|c|c|c|c|c|c|}
\hline \multirow{2}{*}{ Plastic } & \multicolumn{2}{|c|}{ Tubers at 75 days after planting } & \multicolumn{2}{c|}{ Final yield at 120 DAP } \\
\cline { 2 - 6 } & $\begin{array}{c}\text { Number } \\
\text { of tubers } \\
\text { per plant }\end{array}$ & $\begin{array}{c}\text { Average } \\
\text { tuber } \\
\text { weight }\end{array}$ & $\begin{array}{c}\text { Yield } \\
\text { (g/plant) }\end{array}$ & $\begin{array}{c}\text { Marketab } \\
\text { le yield } \\
\text { (ton/fed.) }\end{array}$ & $\begin{array}{c}\text { Yield increase } \\
\text { as \% of the } \\
\text { untreated }\end{array}$ \\
\hline Control & \multicolumn{5}{|c|}{$\mathbf{2 0 1 1 - 2 0 1 2}$} \\
Red & 5.10 & 63.28 & 321.67 & 9.306 & 100 \\
Blue & 5.87 & 95.36 & 543.00 & 20.362 & 222.75 \\
Black & 5.78 & 63.95 & 368.67 & 14.643 & 157.60 \\
\hline L.S.D. at5\% & 6.47 & 79.63 & 513.33 & 18.957 & 204.03 \\
\hline & $\mathbf{1 . 2 7}$ & $\mathbf{2 0 . 2 9}$ & $\mathbf{2 2 . 9 7}$ & $\mathbf{2 . 9 3}$ & $\mathbf{3 1 . 5 8}$ \\
\hline Control & \multicolumn{5}{|c|}{$\mathbf{2 0 1 2 - 2 0 1 3}$} & 100 \\
Red & 5.00 & 66.29 & 332.67 & 9.350 & 216.84 \\
Blue & 5.96 & 94.51 & 564.00 & 20.348 & 157.39 \\
Black & 5.59 & 72.73 & 405.67 & 14.769 & 196.32 \\
\hline L.S.D. at5\% & 6.80 & 79.50 & 538.33 & 18.423 & $\mathbf{2 2 . 5 1}$ \\
\hline
\end{tabular}

concern, highest average number of tubers/plant was recorded with black polyethylene mulching (6.54) and lowest with bare soil (5.50). Higher number of tubers recorded under black plastic mulching may be due to more congenial soil temperature and soil moisture (Figures $1 \& 2$ ), which resulted in better tuberization. The results are in agreement with report by Patel et al. (1999), Singh and Zakwan (2008) on relationship of number of tubers per plant and size of tubers as affected by temperature.

There were also statistically differences in average tuber weight and average yield per plant at 75 DAP during both seasons of study. In this regard, the highest mean tuber weight and tubers yield per plant of $94.94 \mathrm{~g} /$ tuber and $553.5 \mathrm{~g} /$ plant recorded with red polyethylene mulching which were significantly superior to $79.46 \mathrm{~g}$ per tuber and 525.83 per plant obtained with black polyethylene mulching and $64.79 \mathrm{~g}$ per tuber and $327.17 \mathrm{~g}$ per plant with bare soil, in the two seasons respectively. These results support the hypothesis that yield differences associated with colored plastic mulches were due to differences in the spectral characteristics of reflected light, which differed from one to another...this results were harmony with reported by Ferdoushi et al. (2010) suggested that the highest yield of potato tuber $(25.53 \mathrm{t} / \mathrm{ha}$ ) was obtained from the plants grown over black polythene mulch and the lowest $(13.68 \mathrm{t} / \mathrm{h})$ from the plants given no mulch treatments. Contra results, reported by Al-jubouri (2011) on potato and Al-juboori (2013) on garlic they reported that, the highest yield of 
potato and garlic were significantly increased with using red polyethylene mulch compared with non-mulch while the black mulch was effective on some growth aspects.

Marketable yield was higher with red polyethylene mulching and it was statistically at par with black polyethylene mulching treatment, and both were significantly superior to no mulching. Similar trend was obtained in case of average tuber weight. The better results obtained with red plastic mulching followed by black plastic mulching treatment may be due to more favourable temperature for better emergence and increased number of main stems which due to increase number of tubers per plant Table (2) and good growth resulting Table (3) in bigger tuber size. Other workers (Al-jubouri, 2011 on potato and Al-juboori, 2013) on garlic also reported similar findings. Thus, it can be concluded from them studies that the marketable yield was significantly increased under red plastic mulch comparative with non-mulching.

\section{Chemical constituents:}

Chlorophyll content in plant leaves.

Data in Table (5) reveal that, all colored plastic mulched were significantly influenced compared with bare soil treatment. The maximum values of all measured photosynthetic pigments, i.e. chlorophyll $a, b$ and total chlorophyll $(a+b)$ were obtained as a result of using red plastic mulch during both season of this study. In addition, the black mulch resulted the high value in chlorophyll $\mathrm{a}, \mathrm{b}$ and total chlorophyll $(\mathrm{a}+\mathrm{b})$ compared with blue mulch but this increment was significant during 2011/2012 season while, it was not quite reaching a statistically significant level in the 2012/2013 season. Red mulch gave the highest values of all measured photosynthetic pigments, maybe due to the red surface reflected more light and a high ratio of far-red (FR) relative to red (R) light compared to black and blue surface. The ratio acts through the phytochrome system to regulate stem elongation, chloroplast development and photosynthate partitioning among shoots, roots and developing. Similar result was reported by Panchal et al. (2001) who found that mulch had significant effect on total chlorophyll contents in chili.

\section{Minerals contents in leaves:}

The effect of colored plastic mulches on nitrogen $(\mathrm{N})$, phosphorus $(\mathrm{P})$ and potassium $(\mathrm{K})$ contents in plant foliage is illustrated in Table 6 . The nitrogen, phosphors and potassium contents in plant leaves were increased significantly with using polyethylene mulches compared with bare soil treatment. The highest NPK contents were recorded in case of red plastic 
Table 5. Chlorophyll content of potato fresh leaves as affected by colored mulches.

\begin{tabular}{|c|c|c|c|}
\hline \multirow{2}{*}{ Plastic colors } & $\begin{array}{c}\text { Chlorophyll (a) } \\
\text { mg } \\
\text { /100g F W }\end{array}$ & $\begin{array}{c}\text { Chlorophyll (b) } \\
\text { mg /100g F W }\end{array}$ & $\begin{array}{c}\text { Chlorophyll (A+b) } \\
\text { mg /100g F W }\end{array}$ \\
\hline Control & 135.71 & $\mathbf{2 0 1 1 - 2 0 1 2}$ \\
\hline Red & 159.22 & 48.41 & 184.13 \\
\hline Blue & 145.45 & 56.50 & 215.72 \\
\hline Black & 150.67 & 51.54 & 196.99 \\
\hline L.S.D. at5\% & $\mathbf{5 . 3 8}$ & 55.17 & 205.84 \\
\hline & & $\mathbf{3 . 8 7}$ & $\mathbf{8 . 8 9}$ \\
\hline Control & 120.92 & $\mathbf{2 0 1 2 - 2 0 1 3}$ & 164.41 \\
\hline Red & 140.81 & 43.49 & 191.77 \\
\hline Blue & 127.10 & 50.96 & 170.64 \\
\hline Black & 132.35 & 43.54 & 179.97 \\
\hline L.S.D. at5\% & $\mathbf{3 . 0 8 . .}$ & 47.62 & $\mathbf{2 . 5 9 . . .}$ \\
\hline
\end{tabular}

Table 6: Nitrogen $(\mathrm{N})$, phosphorus $(\mathrm{P})$ and potassium $(\mathrm{K})$ content in plant foliage as affected by plastic colored mulches.

\begin{tabular}{|l|c|c|c|}
\hline \multicolumn{1}{|c|}{ Plastic colors } & $\begin{array}{c}\mathbf{N} \\
\text { (mg/g DW) }\end{array}$ & $\begin{array}{c}\mathbf{P} \\
(\mathbf{m g} / \mathbf{g} \text { DW })\end{array}$ & $\begin{array}{c}\text { K } \\
\text { (mg/g DW) }\end{array}$ \\
\hline & \multicolumn{3}{|c|}{$\mathbf{2 0 1 1 - 2 0 1 2}$} \\
\hline Control & $30.40 \mathrm{~d}$ & $1.70 \mathrm{c}$ & $27.40 \mathrm{a}$ \\
Red & $35.25 \mathrm{a}$ & $2.35 \mathrm{a}$ & $27.55 \mathrm{a}$ \\
Blue & $33.60 \mathrm{c}$ & $1.95 \mathrm{~b}$ & $26.80 \mathrm{~b}$ \\
Black & $34.35 \mathrm{~b}$ & $2.05 \mathrm{~b}$ & $13.15 \mathrm{c}$ \\
\hline L.S.D. at5\% & $\mathbf{0 . 7 1}$ & $\mathbf{0 . 2 1}$ & $\mathbf{0 . 4 5}$ \\
\hline & & $2012-2013$ \\
\hline Control & $31.40 \mathrm{c}$ & $1.70 \mathrm{~b}$ & $29.00 \mathrm{a}$ \\
Red & $37.25 \mathrm{a}$ & $2.30 \mathrm{a}$ & $28.05 \mathrm{~b}$ \\
Blue & $33.90 \mathrm{~b}$ & $1.85 \mathrm{~b}$ & $27.80 \mathrm{~b}$ \\
Black & $35.00 \mathrm{~b}$ & $1.95 \mathrm{c}$ & $13.90 \mathrm{c}$ \\
\hline L.S.D. at5\% & $\mathbf{1 . 7 1}$ & $\mathbf{0 . 3 5}$ & $\mathbf{0 . 6 2}$ \\
\hline
\end{tabular}

mulch followed by black plastic mulch. However, the lowest values of these contents were recorded to bare soil treatment. The differences were 
insignificant among the black and blue mulches on nitrogen content in the second season and phosphorus during the first season only.

\section{Cost benefits analysis.}

Cost benefit analysis was done with a view to observing the comparative cost and benefit trend of potato cultivation as influenced by colored plastic mulches. The details of economic analysis have been presented in Table 7 . The total cost of production ranged between LE. $11000 /$ fed. to LE. 13450/fed. among the treatment combination, the variation occurred due to the cost of seed tuber, different mulching and fertilizer management practices.

The highest cost of production 13450 LE. /fed. was involved when red polyethylene mulch was used. The highest gross return 50333 LE. /fed. was found from red polyethylene mulch and the lowest gross return 19523 LE./fed. was obtained from the bare soil treatment. Red polyethylene mulch gave the highest net return 36883 LE. Followed by black mulch 32043 LE.

Table 7. Cost and return of potato production as influenced by mulching.

\begin{tabular}{|c|c|c|c|c|c||}
\hline $\begin{array}{c}\text { Beneficial ratio } \\
\text { (gross ratio } \begin{array}{c}\text { :total } \\
\text { cost) }\end{array}\end{array}$ & $\begin{array}{c}\text { Net return } \\
\text { L.E/fed. }\end{array}$ & $\begin{array}{c}\text { Total cost of } \\
\text { production } \\
\text { L.E/fed. }\end{array}$ & $\begin{array}{c}\text { Gross } \\
\text { return } \\
\text { L.E/fed. }\end{array}$ & $\begin{array}{c}\text { Yield } \\
\text { ton/fed. }\end{array}$ & Treatments \\
\cline { 1 - 4 } & \multicolumn{3}{|c||}{$\mathbf{2 0 1 1 - 2 0 1 2}$} \\
\hline 1.77 & 8523 & 11000 & 19523 & 7809 & Control \\
\hline 3.74 & 36883 & 13450 & 50333 & 20133 & Red \\
\hline 3.02 & 27193 & 13450 & 40643 & 16257 & Blue \\
\hline 3.38 & 32043 & 13450 & 45493 & 18197 & Black \\
\hline & & \multicolumn{3}{|c|}{$\mathbf{2 0 1 2 - 2 0 1 3}$} & \\
\hline 1.80 & 4836 & 11000 & 15836 & 7918 & Control \\
\hline 3.71 & 26436 & 13450 & 39886 & 19943 & Red \\
\hline 2.58 & 14354 & 13450 & 27804 & 13902 & Blue \\
\hline 3.39 & 23034 & 13450 & 36484 & 18242 & Black \\
\hline
\end{tabular}

Conclusively, from the above-mentioned investigation, it can be concluded that utilizing red plastic mulch in the winter on the soil can raise the temperature and moisture around the root zone to get the highest and fastest rate of emergence of the potato seed tubers as well as increasing the vegetative growth parameters, higher total yield and marketable yield with lower production costs than bare soil. 


\section{REFERANCES}

Ahmed, S. M., S. K. Sadik and O. H. Muslah. 2009. Effect of manures and mulching on yield of potato (Solanum tuberosum L.) Desiree. Al-Anbar J. of Agric. Sci., 2 (7) 104-115.

Alam, M.S., M. T. Iqbal, M.S. Amin and M.A. Gaffer. 1989. Krishitattik Fasaler Utpudan O Unnayan. Pub. By T.M. Jubair Bin IQBAL, Vill. Manik Potal, Meghai, Sirajonj. Pp. 231-239.

Al-juboori, A. H. 2013. Effect of planting dates on the yield and quality of garlic by application plastic mulch. Mesopotamia J. of Agric. , 41 (1) 81-90.

Al-jubouri, A. H. 2011. The response of two cultivars of potatoes to soil mulching with different type of polyethylene under conditions of Mosul Region. J. of Kirkuk Univ. For Agric. Sci., 2 (2) 9-18.

Analytical Software. 2008. Statistix 9.0. Analytical Software, Tallahassee, FL.

Ashrafuzzaman, M., M. Abdul Halim, S.M. Shahidullahn and M. Alamgir. 2011. Effect of Plastic Mulch on Growth and Yield of Chilli (Capsicum annuumL.). Brazilian Archives of Biology and Echnology, 54 (2) 321-330.

Brown, I. D. and O. Lilleland, 1946. Determination of potassium and sodium in plant material and soil extracts by flame photometry. Proc. Amer. Soc. Hort. Sci. 48:341-346.

Coling, C. 1997. Effect of plastic film mulching on increasing potato yield:.Acta Agric. Zhojangensis, 9: 83-86.

DuBois, M., K. Gilles, J. Hamilton, P. Rebers, and F. Smith, 1956. Colorimetric method for determination of sugars and related substances. Analytical Chemistry, 28(3): 350-356.

FAO. 2008. International Year of the Potato - Global potato economy. Retrieved 15-02-2013.

Ferdoushi, S.N., A.M. Farooque and M.S. Alam. 2010. Effects of organic and inorganic fertilizer management practices and mulch on the growth and yield of potato. Agrofor. Environ., 3 (2): 175-178.

Fortnum, B. A., D. R. Decoteau, M. J. Kasperbauer, and W. Bridges. 1995. Effect of coloured mulches on root-knot of tomato. Phytopathology, 85: 312-318.

Jalil, M.A.,M.A.K. Azad and A.M. Farooque. 2004. Effect of Different Mulches on the Growth and Yield of Two Potato Varieties. Journal of Biological Sciences, 4: 331-333.

John, M.K. 1970. Colorimetric determination of phosphorus in soil and plant materials with ascorbic acid. Soil Since, 109 (4):214-220. 
Masud, M.M., K. Farooq, H. Amjad and R. Sher. 2002. Effect of mulching on growth and yield of potato crop. Asian J. of plant Sci. 1 (2)132-133.

Murphy, J., and J.P. Riley. 1962. A modified single solution method for the determination of phosphate in natural waters. Anal. Chim. Acta, 27:3136.

Panchal, S. C., Bhatnagar, R., Momin, R. A. and Chauhan, N. P. (2001). Influence of cultural practices on quality of green and red chilli (Capsicum annum L.) fruit. Indian J. Agric. Biochem., 14, 21-24.

Park, S. U., K. Y. Park, Y. K. Kang, and S. K. Jong. 1987. Effect of polythene mulching and tunnel on the growth and yield of early produced sweet corn. Res. Rep. Rural Dev. Adm. Crops, 29: 245-250.

Patel, H.R., A.M. Shekh, G.C. Patel, D.S. Mistry and C.T. Patel. 1999. Influence of soil temperature on potato emergence. J. Indian Potato Assoc., 26: 23-26.

Perkins, F. 1994. Practical Cost Benefit Analysis: Basic Concepts And Applications. Macmillan Education, San Marino.

Petrov, K. H. and M. Al-Amiri. 1976. Soil mulching in early field tomato production. Grandinarstvo57:17-20.

Pregl, F. 1945. Quantitative Organic Microanalysis. 4th Ed. Churchill, London.

Sadik K. 2009. Effect of manures and mulching on quality characters of potatoes (Solanum tuberosum L.) cv. Desiree. AL-Anbar J. of Agric. Sci., 2 (7): 116-127.

Singh, N. and A. Zakwan. 2008. Effect of mulching on potato production in high altitude cold arid zone of ladakh. Potato J. ,35 (3 - 4): 118-121.

Suwon. M.A and O.M. Judah. 1985. Influence of plastic mulching on growth and yield and soil moisture conservation in plastic house tomatoes. Dirasat, 12, 21-23.

Wang, X. Q., S. X. Li and Y. J. Gao. 1998. Effect of plastic film mulching on Eco physiology and yield of spring maize on arid lands. Acta Agronomica Sinica, 24:348-353.

Yoshida, S. D. Forna, J. Cock and K. Gomez. 1976. Determination of chlorophyll in plant tissues. In Laboratory Manual of physiological studies of rice. The international Rice Research Inst. Los Banos, Laguna. Philippines. Pp. 43-45. 
تأثير الأغطية البلاستيكية الملونة على الإنبات والنمو والمحصول القابل للتسويق في البطاطس

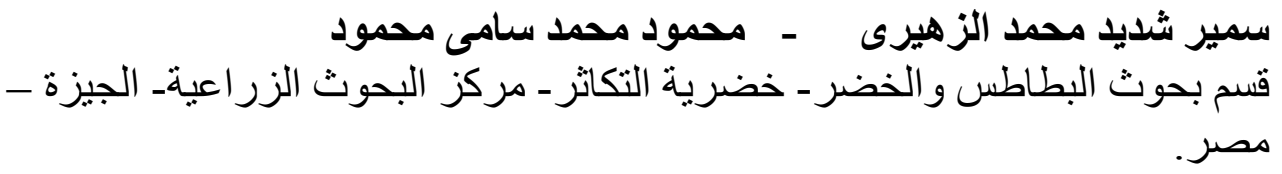

أجريت تجربتان حقليتان في المزرعة البحثية، لمعهد بحوثا لبساتين-مركز

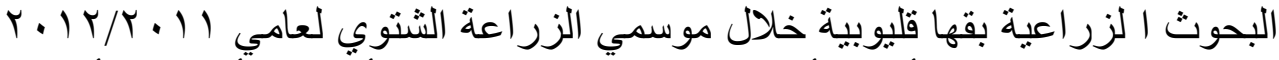

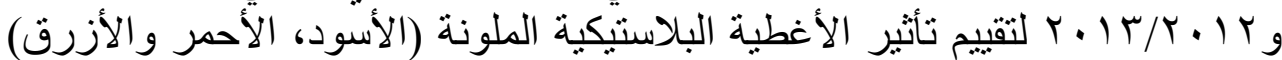

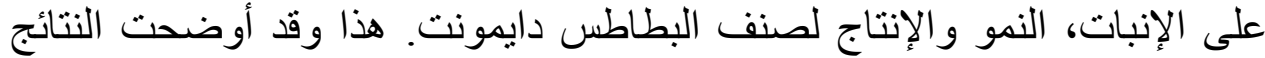
المتحصل عليها أن هناك اختلافات معنوية فيما بين الأغطية البالاستيكية الملونة على الإنى

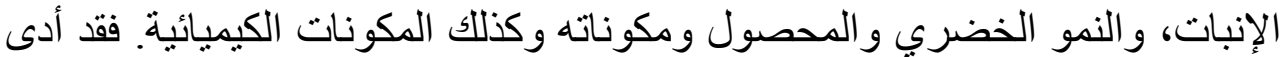

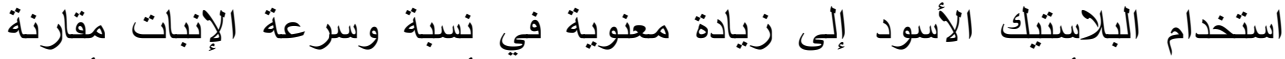

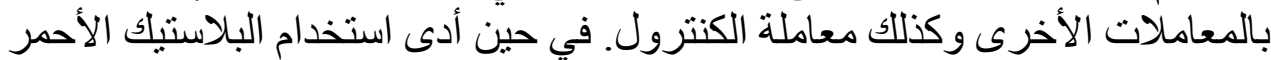

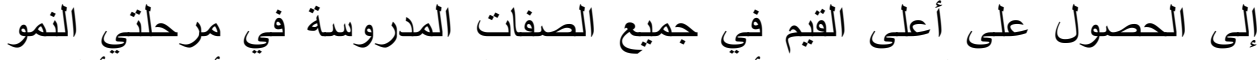

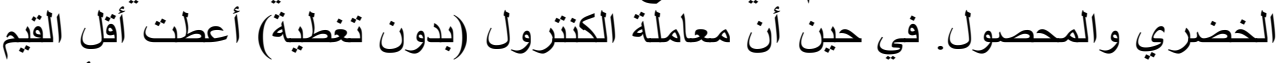

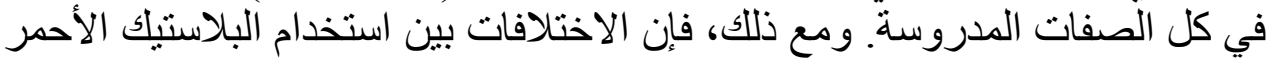

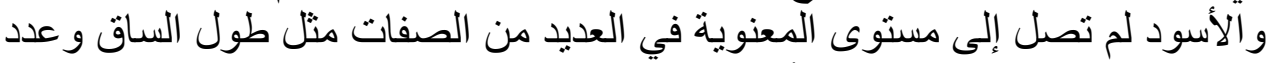

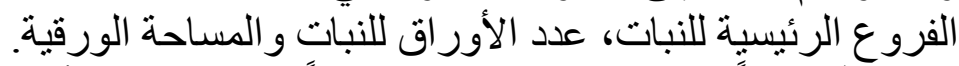

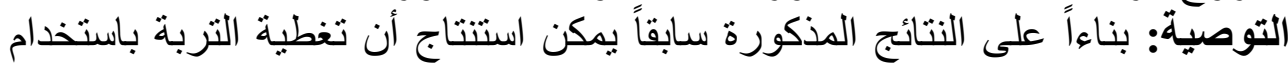
البلاستيك الأحمر أدى إلى رفع درجة حرارة ورطوبة التربة في منطقة الجذور مما

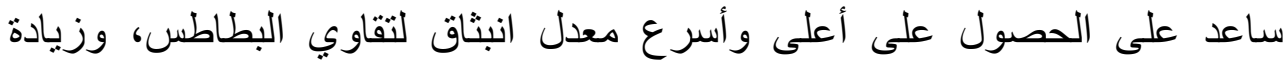

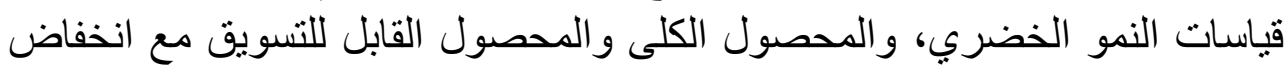
تكاليف الإنتاج مقارنة بالزر اعة التقليدية واليدية 